\title{
Colletotrichum graminicola from leaves or stalks are similarly aggressive in cross-tissue inoculation of five maize hybrids
}

\author{
Alessandro Nicoli ${ }^{1,2}$ - Laércio Zambolim ${ }^{1} \cdot$ Rodrigo Veras da Costa $^{3}$. \\ Luciano Viana $\operatorname{Cota}^{3} \cdot$ Dagma Dionísia da Silva ${ }^{3}$
}

Received: 21 April 2015 / Accepted: 20 November 2015 /Published online: 30 November 2015

(C) Sociedade Brasileira de Fitopatologia 2015

\begin{abstract}
The objective of this study was to assess whether the source of Colletotrichum graminicola isolates (leaves or stalks) affects anthracnose leaf blight (ALB) and anthracnose stalk rot (ASR) development. Ten greenhouse experiments were conducted, five to evaluate ALB and five to evaluate ASR, each using a distinct commercial maize hybrid varying in reaction to the diseases. A collection of 20 isolates, 10 recovered from symptomatic leaves, and ten from symptomatic stalks, were inoculated on the five hybrids. Maize leaves were inoculated 15 days after planting and ALB was evaluated 15 days after inoculation. Stalks were inoculated at pretasseling and ASR evaluated 30 days later. Both ALB and ASR were assessed using a $0-5$ ordinal scale. No differences in ALB and ASR severity were observed between the two groups of isolates regardless of hybrid based on the non-parametric test. The ability of $C$. graminicola to infect and cause anthracnose on any part of the maize plant seemed to not depend on the source of the isolate.
\end{abstract}

Keywords Zea mays · Anthracnose leaf blight · Anthracnose stalk rot

Section Editor: Paul D. Esker

Alessandro Nicoli

agronicoli@yahoo.com.br

1 Departamento de Fitopatologia, Universidade Federal de Viçosa, Av. P.H. Rolfs, s/n, Campus Universitário, 36570-000 Viçosa, MG, Brazil

2 Present address: Departamento de Agronomia, Área de Fitossanidade, Universidade Federal Rural de Pernambuco, 52171-900 Recife, PE, Brazil

3 Embrapa Milho e Sorgo, Caixa Postal 151, 35701-970 Sete Lagoas, MG, Brazil
Anthracnose of maize, caused by the fungus Colletotrichum graminicola (Ces.) Wils., is among the most important maize diseases (Bergstrom and Nicholson 1999; Chung et al. 2011; Jirak-Peterson and Esker 2011; Frey et al. 2011; Cota et al. 2012; Costa et al. 2014). The fungus attacks the leaves causing the anthracnose leaf blight (ALB) and the stalks causing the anthracnose stalk rot (ASR) disease, both potentially leading to severe economic losses (Badu-Apraku et al. 1987; Bergstrom and Nicholson 1999; Costa et al. 2010a; JirakPeterson and Esker 2011; Cota et al. 2012). Recommended management practices include crop rotation, incorporation of crop residues in the soil, balanced fertilization, adequate plant density and avoidance of injury to the stalk (Bergstrom and Nicholson 1999; Costa et al. 2010a, 2014; Cota et al. 2012).

In addition to cultural methods, studies have reported the potential to use host plant resistance to manage ALB or ASR (Badu-Apraku et al. 1987; Toman and White 1993; Coêlho et al. 2001; Palaversic et al. 2009; Frey et al. 2011; Chung et al. 2011; Matiello et al. 2012). In most of the studies for assessing maize reaction to ALB or ASR, a single aggressive isolate of C. graminicola is used. Cross-inoculation on separate parts of the maize plant with isolates recovered from either symptomatic leaves or stalks has not been considered. Thus, it is of interest to evaluate whether isolates of C. graminicola recovered from leaves or stalk tissue differ in aggressive on the stalk or leaves of maize plants, respectively. Therefore, the aim of this study was to compare ALB and ASR severity induced by two sets of isolates grouped by their tissue of origin.

To explore this objective, ten greenhouse experiments were conducted, five to evaluate ALB, and five to evaluate ASR. Each experiment used twenty $C$. graminicola isolates, and was defined by a single commercial hybrid varying in susceptibility to the anthracnoses. The hybrid BRS1010 is considered susceptible to anthracnose (Costa et al. 2010b; Cota et al. 
2010), 2B710 is considered resistant to ALB and ASR (Costa et al. 2010b, 2014; Cota et al. 2010; Carvalho et al. 2013), 2B707 is considered resistant to stalk disease, and P30F35 and P3862 are considered moderately resistant to stalk disease (Cruz et al. 2013).

Among the twenty $C$. graminicola isolates evaluated in this study, ten were recovered from symptomatic stalk and ten were recovered from symptomatic leaves. These isolates were encoded using a numerical system with a prefix as S (stalk) or $\mathrm{L}$ (leaf). Isolates were recovered from maize plants in Sete Lagoas-MG (S1-S6, S8-S10, L1-L7), Chapecó-SC (S7), Campo Mourão-PR (L8-L9) and Cascavel-PR (L10), Brazil (Table 1). In each trial the experimental design was completely randomized, with 21 treatments (twenty $C$. graminicola isolates and one control with water) and three replicates (pots). Inoculum concentration was $10^{6}$ conidia/mL per isolate. Each experiment was performed once, and experiments were conducted sequentially at different time periods due to the space limitations.

For the experiments that examined ALB, four plants were grown in $5 \mathrm{~L}$ plastic pots. Inoculation was performed by spraying the plants to the point of runoff at 15 days after planting, corresponding to growth stages V4-V5 (Miranda et al. 2013). Plants were then maintained at $80 \%$ relative humidity for $15 \mathrm{~h}$ at a temperature of $26 \pm 2{ }^{\circ} \mathrm{C}$. Disease assessments were performed 15 days after inoculation (growth stage V7-V8) using the following rating scale: $\mathbf{1 . 0}$ (no symptoms); $\mathbf{1 . 5}$ to 2.0 (mild infection, presence of a small number of elongated

Table 1 Information for a collection of twenty Colletotrichum graminicola isolates used to inoculate maize leaves and stalks

Code number Organ of origin Municipality (Brazil) Year of sampling

\begin{tabular}{llll}
\hline S1 & stalk & Sete Lagoas - MG & 2007 \\
S2 & stalk & Sete Lagoas - MG & 2007 \\
S3 & stalk & Sete Lagoas - MG & 2007 \\
S4 & stalk & Sete Lagoas - MG & 2007 \\
S5 & stalk & Sete Lagoas - MG & 2007 \\
S6 & stalk & Sete Lagoas - MG & 2007 \\
S7 & stalk & Chapecó - SC & 2007 \\
S8 & stalk & Sete Lagoas - MG & 2008 \\
S9 & stalk & Sete Lagoas - MG & 2008 \\
S10 & stalk & Sete Lagoas - MG & 2008 \\
L1 & leaf & Sete Lagoas - MG & 2008 \\
L2 & leaf & Sete Lagoas - MG & 2008 \\
L3 & leaf & Sete Lagoas - MG & 2008 \\
L4 & leaf & Sete Lagoas - MG & 2008 \\
L5 & leaf & Sete Lagoas - MG & 2008 \\
L6 & leaf & Sete Lagoas - MG & 2008 \\
L7 & leaf & Sete Lagoas - MG & 2009 \\
L8 & leaf & Campo Mourão - PR & 2009 \\
L9 & leaf & Campo Mourão - PR & 2009 \\
L10 & leaf & Cascavel - PR & 2009 \\
\hline
\end{tabular}

lesions without sporulation, up to $10 \%$ of the foliar area affected); 2.1 to 2.5 (mild to moderate severity, presence of elongated lesions without sporulation or hypersensitivity reaction, with $11 \%$ to $15 \%$ of the foliar area affected); 2.6 to $\mathbf{3 . 0}$ (severe infection with large number of sporulating lesions and with some coalescence, $16 \%$ to $20 \%$ of the foliar area affected); 3.1 to 4.9 (severe infection with large number of sporulating lesions and with some coalescence, $21 \%$ to $40 \%$ of the foliar area affected); $\mathbf{5 . 0}$ (very severe infection, with abundant and coalesced lesions; over $40 \%$ of the foliar area affected). If mean scores were equal to or greater than 2.6, plants were considered susceptible (Ferreira and Casela 1986).

For the experiments on ASR, one plant was grown in $20 \mathrm{~L}$ plastic pots and the plants were maintained at a temperature of $26 \pm 2{ }^{\circ} \mathrm{C}$ and at a relative humidity of $40 \pm 10 \%$. Inoculation was performed in the pre-tasseling phase (growth stages V13V15) using an inoculation needle that was dipped in the spore suspension. Plants were inoculated by first removing the lower leaves, exposing the internodes of the stalk base. The surface of the stalk was disinfected with $70 \%$ alcohol and then the third internode above the soil line was perforated with a sterilized manual punch. The toothpick containing the spore suspension was then inserted into the stalk, and remained in the stalk until the time of assessment. Evaluations were performed at 30 days after inoculation, corresponding to growth stages R2-R3 (Miranda et al. 2013). First, stalks were cut longitudinally, and disease severity was scored as follows: $\mathbf{0 . 5}(00.00-12.5 \%$ severity of anthracnose) $\mathbf{1 . 0}$ (12.6 $25 \%) ; \mathbf{1 . 5}(25.1-37.5 \%) ; \mathbf{2 . 0}(37.6-50 \%) ; \mathbf{2 . 5}(50.1-$ $62.5 \%) ; \mathbf{3 . 0}(62.6-75 . \%) ; \mathbf{3 . 5}(75.1-87.5 \%) ; \mathbf{4 . 0}(87.6-$ $100 \%$ ) (Nicoli 2013).

The ALB and ASR scores were first checked against the ANOVA assumptions. The scores data were submitted to analysis the homogeneity of variance with Bartlett's test and for normality with Kolmogorov-Smirnov test, both at the level of $5 \%$ probability. As the data appeared not to satisfy these assumptions, the two groups of C. graminicola isolates (leaves and stalks) were compared as independent samples using a nonparametric Mann-Whitney test (5\% significance level). Analyzes were performed for ALB and ASR, by hybrid, leading to ten separate analyses. The Minitab statistical software (version 14) was used for the data analyses.

The severity of ALB and ASR on the different maize hybrids inoculated with $20 \mathrm{C}$. graminicola isolates are shown in Fig. 1. On the leaves of BRS1010, all isolates caused ALB with severity greater than 3.0. On the stalk, nineteen isolates caused approximately $100 \%$ ASR severity. On the leaves of 2B710, twelve isolates caused ALB with sporulating lesions

Fig. 1 Anthracnose leaf blight (ALB) and anthracnose stalk rot (ASR) scores of five hybrids inoculated with 20 isolates of Colletotrichum graminicola (ten recovered from symptomatic leaf and ten from stalk). a-b (BRS1010); c-d (2B710); e-f (2B707); g-h (P30F35); i-j (P3862) 


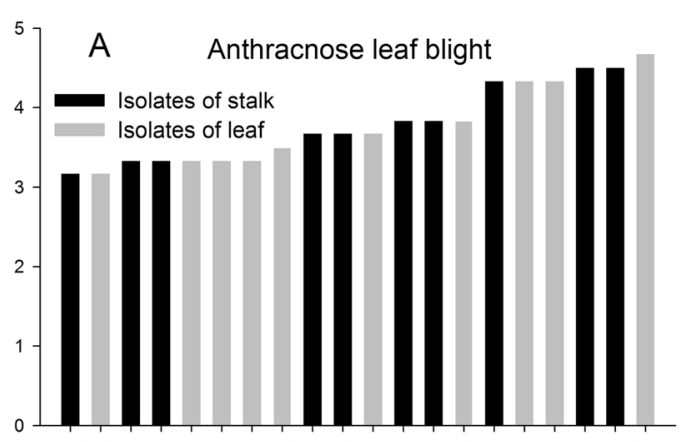

S10 L3 S9 S7 L8 L5 L1 L10 S8 S4 L6 S5 S2 L4 S1 L9 L2 S6 S3 L7

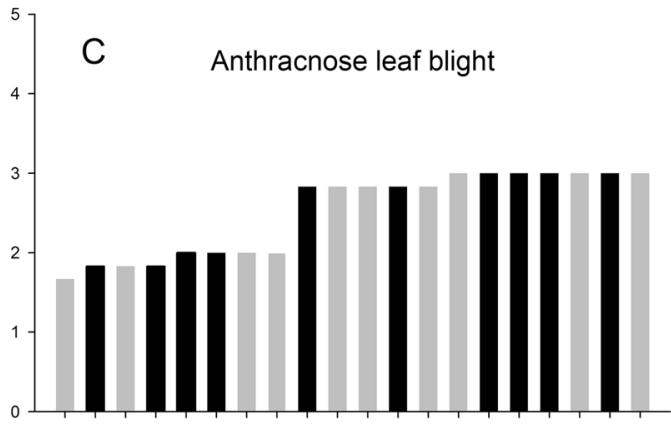

L7 S3 L9 S7 S1 S2 L10 L8 S6 L4 L1 S10 L3 L2 S5 S8 S4 L6 S9 L5

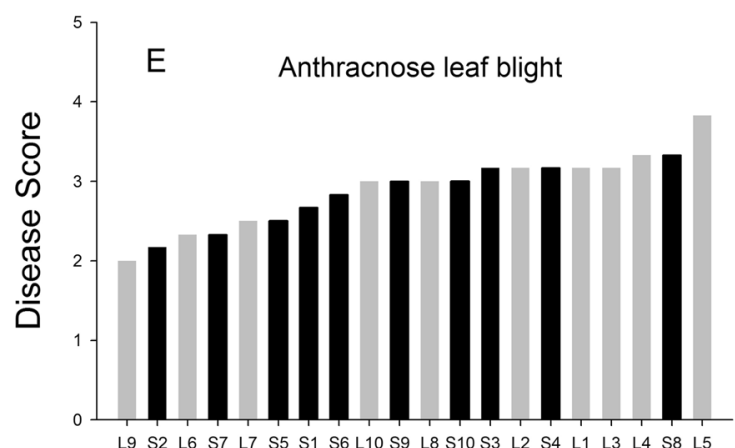

G

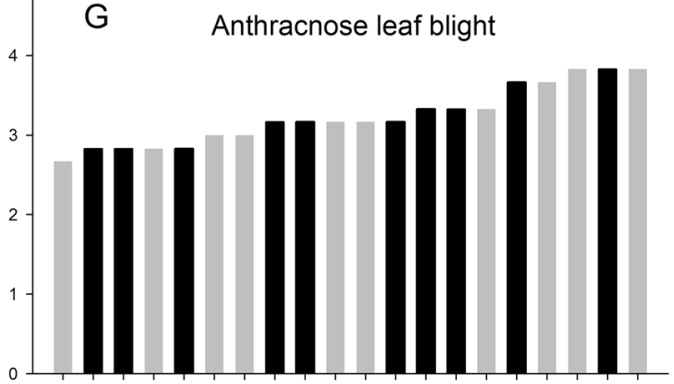

L8 S2 S4 L6 S7 L7 L9 S3 S5 L10 L1 S10 S6 S1 L4 S8 L5 L2 S9 L3

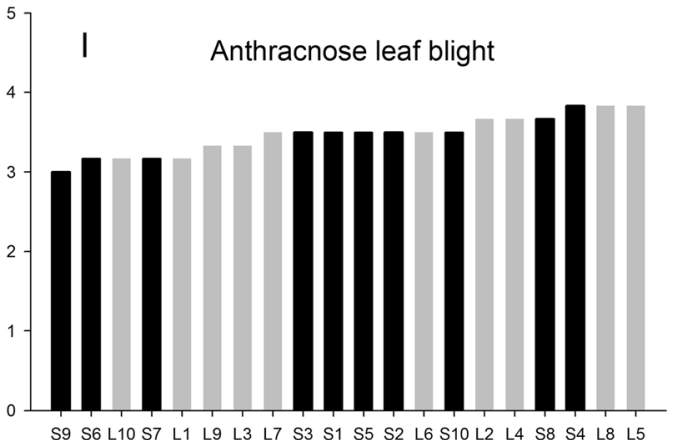

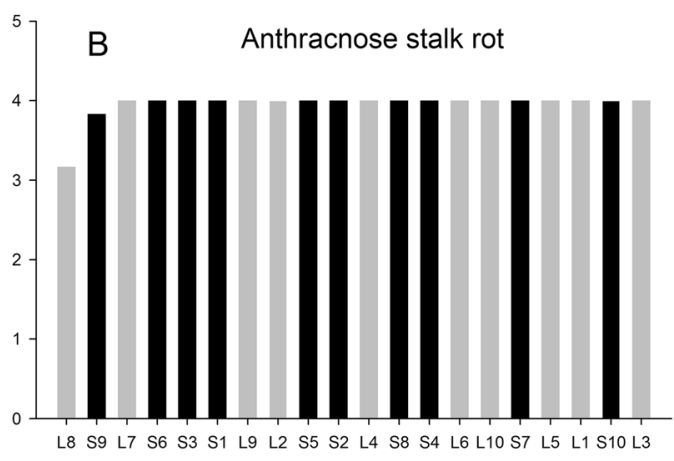
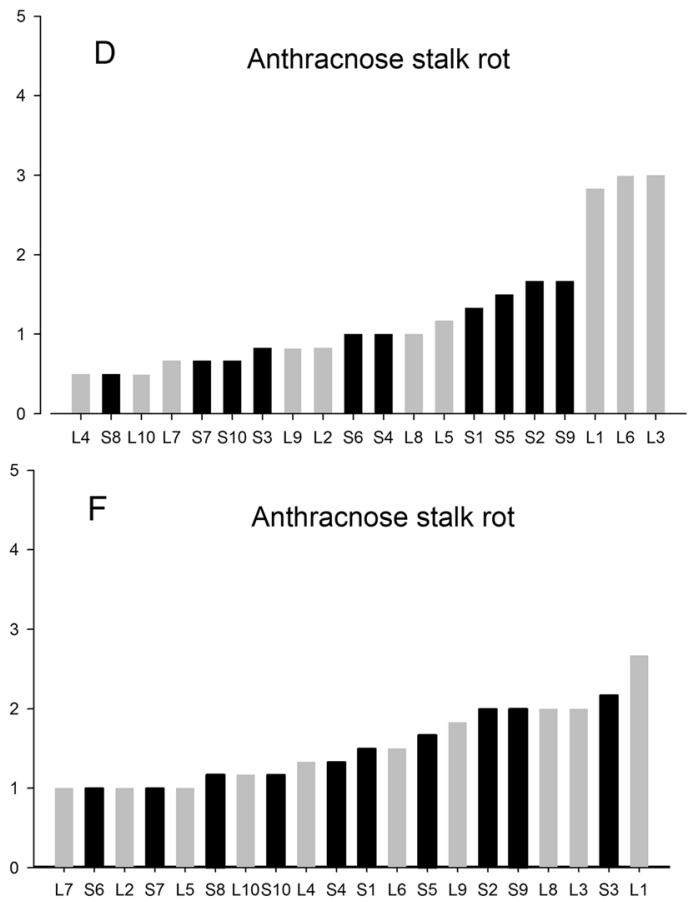

$\mathrm{H}$

Anthracnose stalk rot

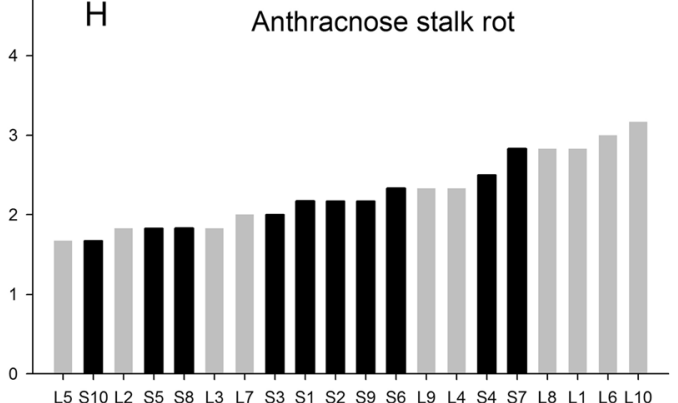

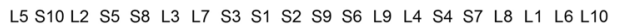

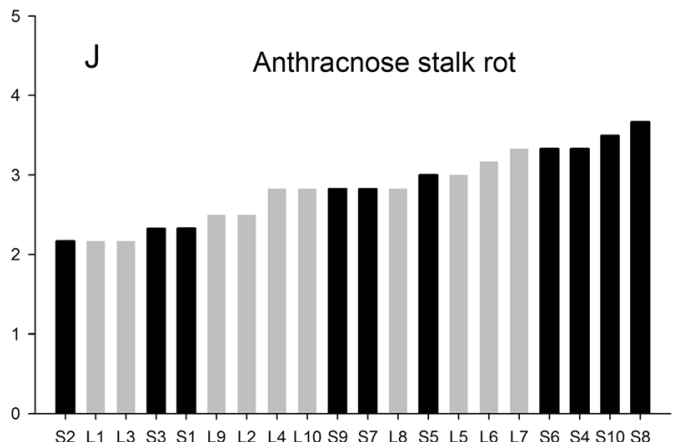


Fig. 2 Mean anthracnose leaf blight (ALB) scores on the five maize hybrids inoculated with groups of Colletotrichum graminicola isolates recovered from symptomatic leaf or stalk tissue. No statistical difference in each hybrid was detected for group of isolates recovered from leaf and stalk tissues (MannWhitney test: $P>0.05)$. Error bars represent the standard error of the mean $(n=10)$

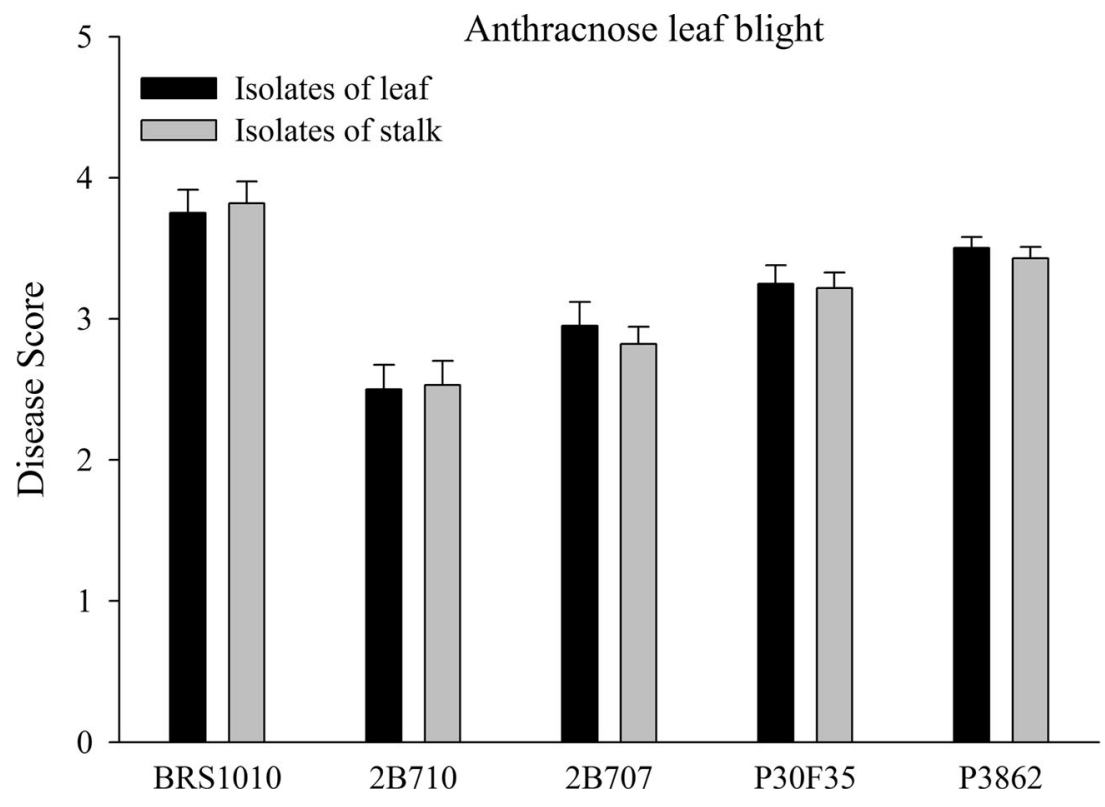

and other eight isolates showed a mild infection without sporulation. On the stalk, only three isolates recovered from leaves caused severity approximately 3.0. On the hybrid 2B707, the isolates caused greater ALB severity than ASR. Those isolates caused severe infection on the leaves of the hybrid P30F35 with sporulating lesions. The severity of ASR in P30F35 was considered moderate when the scores were less than 2.0 and high when the scores were greater than 2.0. On the hybrid P3862, all isolates caused severity greater than 3.0 on the leaves and greater than 2.0 on the stalk.

Mean scores of ALB and ASR for each maize hybrid inoculated with different isolates of $C$. graminicola are shown in Figs. 2 and 3, respectively. Focusing on ALB, isolates obtained from leaf and stalk tissue had the following mean scores: 3.75 and 3.82
(BRS1010), 2.50 and 2.53 (2B710), 2.95 and 2.82 (2B707), 3.25 and 3.22 (P30F35), 3.50 and 3.43 (P3862), respectively (Fig. 2). Mean ASR scores for each hybrid inoculated with isolates recovered from leaf and stalk were 3.92 and 3.98 (BRS1010), 1.43 and 1.08 (2B710), 1.55 and 1.50 (2B707), 2.38 and 2.15 (P30F35), 2.73 and 2.88, respectively (P3862) (Fig. 3).

Furthermore, no differences were observed in terms of the source of isolate, whether from leaf or stalks, on the ALB and ASR severity $(\mathrm{P}>0.05)$. ALB and ASR scores were statistically equal for the two groups of isolates in each hybrid (Figs. 2 and 3). As previously described, C. graminicola survives as a saprophyte in surface corn debris and this is the primary source inoculum at the beginning of the subsequent growing season. The spores of the fungus are dispersed to
Fig. 3 Mean anthracnose stalk rot (ASR) scores on the five maize hybrids inoculated with groups of Colletotrichum graminicola isolates recovered from symptomatic leaf or stalk tissue. No statistical difference in each hybrid was detected for group of isolates recovered from leaf and stalk tissues (MannWhitney test: $P>0.05)$. Error bars represent the standard error of the mean $(n=10)$

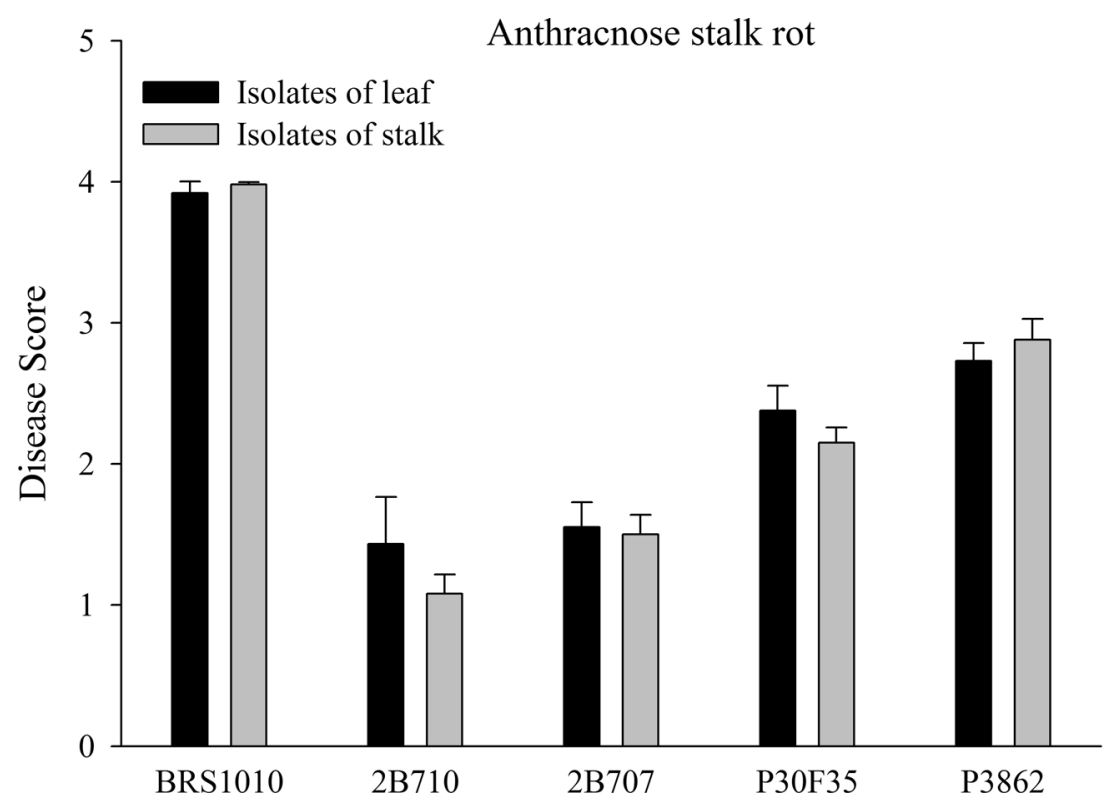


newly emerged seedlings where they infect and cause ALB but produce secondary inoculum for season-long foliar infection as well as for later-season stalk infection. ASR symptoms are more visible after the flowering of the maize plant, but the infection process begins with spores from the foliar lesions or those present in crop residues (Bergstrom and Nicholson 1999; Venard and Vaillancourt 2007; Jirak-Peterson and Esker 2011; Cota et al. 2012).

The response of maize genotypes to C. graminicola may differ depending whether the infection by the pathogen occurs in the leaves or the stalk, thus suggesting different genetic mechanisms of resistance to ALB and ASR (Lim and White 1978; Zuber et al. 1981; Badu-Apraku et al. 1987; Chung et al. 2011). However, regardless of the hybrids, which showed distinct levels of resistance to anthracnose (ALB or ASR), no statistical differences in ALB and ASR severity was found between the group of isolates. Even for the most resistant, hybrid 2B710 (Costa et al. 2010b, 2014; Cota et al. 2010; Carvalho et al. 2013), no difference between the groups of isolates was found. In conclusion, we found no evidence of tissue preference for $C$. graminicola isolates causing ALB and ASR.

Acknowledgments The authors acknowledge the Conselho Nacional de Desenvolvimento Científico e Tecnológico $(\mathrm{CNPq})$ and the Embrapa Milho e Sorgo for providing the financial support.

\section{References}

Badu-Apraku B, Gracen VE, Bergstrom GC (1987) Inheritance of resistance to anthracnose stalk rot and leaf blight in a maize inbred derived from a temperate by tropical germplasm combination. Maydica 32:221-237

Bergstrom GC, Nicholson RL (1999) The biology of corn anthracnose: knowledge to exploit for improved management. Phytopathology 83:596-608

Carvalho DO, Pozza EA, Casela CR, Costa RV, Pozza AAA, Carvalho CO (2013) Adubação nitrogenada e potássica na severidade da antracnose em dois cultivares de milho. Rev Ceres 60:380-387

Chung CL, Poland J, Kump K, Benson J, Longfellow J, Walsh E, BalintKurti P, Nelson R (2011) Targeted discovery of quantitative trait loci for resistance to northern leaf blight and other diseases of maize. Theor Appl Genet 123:307-326

Coêlho RMS, Silva HP, Brunelli KR, Camargo LEA (2001) Controle genético da antracnose foliar em milho. Fitopatol Bras 26:640-643

Costa RV, Silva DD, Cota LV, Parreira DF, Ferreira AS, Casela CR (2010a) Incidência de Colletotrichum graminicola em colmos de genótipos de milho. Summa Phytopathol 36:122-128
Costa RV, Cota LV, Parreira DF, Silva DD, Guimarães PE, Guimarães LJM, Parentoni SN, Pacheco CA (2010b) Desenvolvimento de metodologia para inoculação de Colletotrichum graminicola em colmo de milho. Embrapa Milho e Sorgo (Circular técnica, 139), Sete Lagoas

Costa RV, Cota LV, Silva DD, Parreira DF, Casela CR, Landau EC, Figueiredo JEF (2014) Races of Colletotrichum graminicola pathogenic to maize in Brazil. Crop Prot 56:44-49

Cota LV, Costa RV, Guimarães PE, Guimarães LJM, Parentoni SN, Pacheco CA, Silva DD, Parreira DF (2010) Métodos de inoculação de Colletotrichum graminicola em colmo de milho. Embrapa Milho e Sorgo (Circular técnica, 137), Sete Lagoas

Cota LV, Costa RV, Silva DD, Casela CR, Parreira DF (2012) Quantification of yield losses due to anthracnose stalk rot on corn in Brazilian conditions. J Phytopathol 160:680-684

Cruz JC, Pereira Filho IA, Queiroz LR. Milho - Cultivares para 2013/2014. Embrapa Milho e Sorgo. Disponível em: <http://www. cnpms.embrapa.br/milho/cultivares/index.php>. Acessado em: 20 de Novembro de 2014.

Ferreira AS, Casela CR (1986) Raças patogênicas de Colletotrichum graminicola, agente causal da antracnose do sorgo (Sorghum bicolor (L.) Moench). Fitopatol Bras 11:83-86

Frey TJ, Weldekidan T, Colbert T, Wolters PJCC, Hawk JA (2011) Fitness evaluation of Rcgl, a locus that confers resistance to Colletotrichum graminicola (Ces.) G.W. Wils. Using near-isogenic maize hybrids. Crop Sci 51:1551-1563

Jirak-Peterson JC, Esker PD (2011) Tillage, crop rotation, and hybrid effects on residue and corn anthracnose occurrence in Wisconsin. Plant Dis 95:601-610

Lim SM, White DG (1978) Estimates of heterosis and combining ability for resistance of maize to Colletotrichum graminicola. Phytopathology 68:1336-1342

Matiello RR, Brunelli KR, Lopes MTG, Morello RMSC, Silva HP, Camargo LEA (2012) Inheritance of resistance to anthracnose stalk rot (Colletotrichum graminicola) in tropical maize inbred lines. Crop Breed Appl Biotechnol 12:179-184

Miranda GV, Santos IC, Galvão JCC, Paula-Júnior TJ, Nicoli A, Lemos JP (2013) Guia técnico para produção de milho, 2nd edn. EPAMIG, Viçosa, 53p

Nicoli A (2013) Resistência à antracnose do colmo em milho: escala de avaliação, marcador molecular e correlação da severidade entre colmo e folha. Tese de Doutorado, Departamento de Fitopatologia, Universidade Federal de Viçosa, Viçosa

Palaversic B, Jukic M, Buhinicek I, Vragolovic A, Kozic Z (2009) Breeding maize for resistance to stalk anthracnose. Maydica 54: 229-232

Toman Júnior J, White DG (1993) Inheritance of resistance to anthracnose stalk rot of corn. Phytopathology 83:981-986

Venard C, Vaillancourt L (2007) Colonization of fiber cells by Colletotrichum graminicola in wounded maize stalks. Phytopathology 97:438-447

Zuber MS, Ainsworth TC, Blanco MH, Darrah LL (1981) Effect of anthracnose leaf blight on stalk rind strength and yield in $F_{1}$ single crosses in maize. Plant Dis 65:719-722 